\title{
Community Development as Disaster Risk Reduction Efforts through the Disaster Resilient Village (Destana) Program in Nganjuk Regency
}

\author{
Novianti Luluk Mahbubah ${ }^{\mathbf{1}}$, Mochamad Faizal Rizki ${ }^{2}$, Haura Atthahara ${ }^{3}$ \\ 1,2,3 Department of Government Studies, Faculty of Political and Social Sciences, Universitas \\ Singaperbangsa, Karawang \\ Jl.HS Ronggo Waluyo, Paseurjaya, Telukjambe, Karawang, West Java, Indonesia 41361
}

*Corresponding author: novianti@gmail.com

\section{ABSTRACT}

Article Info :

The high index of disaster risk in Nganjuk Regency shows the potential victims' magnitude and the impact of existing disasters. Nganjuk Regency is one of the areas with a high potential threat of disaster with lowland and mountainous topography, causing several disasters such as floods, landslides, land and forest fires, drought, and strong winds/tornadoes, plus the lack of public knowledge in disaster management. This study aims to analyze the Regional Government's efforts through the Regional Disaster Management Agency (BPBD) of Nganjuk Regency to implement the Disaster Resilient Village (Destana) program in disaster-prone villages in Nganjuk Regency. The Destana program is a community development activity to reduce risk, so the community is expected to be resilient in facing disasters. In research using qualitative research methods with a descriptive approach. The data collection techniques used were field observation, in-depth interviews, and documentation. The results of this study indicate that the Destana program established by BPBD Nganjuk Regency by developing disaster-prone communities has been able to reduce existing disaster risks by forming a resilient and independent community in dealing with disasters.

\section{INTRODUCTION}

The Republic of Indonesia Government Law Number 24 the Year 2007, a disaster is an event or a collection of several events that threaten people's lives caused by natural factors, non-natural factors and human factors that cause environmental damage, loss of property, the emergence of victims human spirit, and psychological impact. The phenomenon of the disaster continues to this day. So, we must understand

Please cite this article as: Mahbubah, N. L., Rizki, M. F. ., \& Atthahara, H. . (2021). Community Development as Disaster Risk Reduction Efforts through the Disaster Resilient Village (Destana) Program in Nganjuk Regency. Journal of Local Government Issues (LOGOS), 4(1), 60-76. https://doi.org/10.22219/logos.v4i1.13116 
what causes the disaster is still coming today. Also, we must know the impact that will arise and how to survive from the emergence of disaster phenomena (Kodoatie, 2006).

Thus everyone has the right to get protection and a sense of security, especially for disaster-prone community groups. Protection is implemented from disaster management from the beginning or before the disaster emerged through preparedness up to the post-disaster stage, namely social recovery. Seeing this, the Regional Disaster Management Agency (BPBD) refers to the Law of the Government of the Republic of Indonesia Number 24 of 2007 concerning Disaster Management. In the same law in article 37, paragraphs 1 and 2 states that disaster risk reduction activities are a concept and practice to reduce the adverse impacts that may arise from a disaster, primarilycarried out in a situation where no disaster occurs through some systematic efforts to analyze and reduce the factors that cause disasters., placing the importance of active community participation in disaster management. In connection with this, BNPB established a program related to community-based disaster management for disaster risk reduction named Disaster Resilient Villages (Destana). The activity is carried out by citizens from the village, sub-regency to local governments that are categorized as disaster-prone areas through the assistance of the Regional Disaster Management Agency (BPBD).

It is reinforced by the enactment of the Head of BNPB Regulation No. 1 of 2012 concerning General Guidelines for Disaster Resilient Villages (Destana), which states that Destana is a village that can independently adapt and deal with the potential threat of a disaster that occurs. Where the strategy towards an independent village is 1) building capacity of citizens and civil society organizations in villages that are critical and dynamic, 2) strengthening capacity and interaction between the community and village government, 3) building a participatory planning and budgeting system, and 4) building economic institutions productive locality (Yustika, 2015). In this case, the village is considered capable of recovering immediately from the effects of the disaster. The village has the authority to carry out development, governance, community empowerment, and community coaching in disaster response/alert activities. Based on Regulation of The Minister of Internal Affairs of The Republic of Indonesia Number 81 2015 about Evaluation of Village and sub-regency Development in terms of disaster response/alert, villages must pay attention to 1) village contingency planning, 2) disaster risk maps, 3) community-centered early warning systems, and 4) Evacuation infrastructure. In reality, village community empowerment, village development, and village community development is an inseparable part of village governance (Kushandajani, 2017). The success of implementing community development in the village cannot be separated from the village government's role in its ability to carry out community empowerment and community development to reduce the risk of disaster.

Community development as a participatory approach that emphasizes the community's solidarityto solve existing problems. In a community, its members' activities are characterized by participation and direct involvement (Bhattacharyya, 2004). All community self-help efforts are integrated with the local government's efforts to improve the standard of living of the community by increasing community initiatives, the formation of services that encourage communities to be self-sustaining, mutual assistance, and encourage the emergence of initiatives so that development is effective.

\section{1| Journal of Local Government Issues (Logos), 4 (1), March 2021, pp 60- 75 ISSN : 2620-8091 print | 2620-3812 online}


A community must have a certain locality permanently and permanently to have a strong solidarity bond to underline between social relations and particulargeographical areas (Nasdian, 2015). Where the community mentioned is considered as solidarity (identity and shared norms) which from the beginning were in the field such as rural residential environment there is agriculture, the urban environment there is an industry and other environments that have stood places or spaces so that it becomes an inseparable part or thing from the community. Thus, whether rural, urban, or whatever, the place has become another element of the concept of community transcended to achieve the theory of community development. Community development aims are to pursue solidarity and agency by sticking to the principles of self-help, perceived needs, and participation.

These three principles are considered the suitablemethod for community development practices. From these principles, it will be used as a benchmark to determine the community's actions in representing an activity carried out by the community in solving problems that exist in the scope of their community. According to (Bhattacharyya, 2004), principles as a method of community development practice areincreasing solidarity and institutionalization in a self-help manner, community participation, and needs that are shared. These three principles provide the necessary guidance for community development practices in reducing the risk of disasters arising by acting as agents from the start. Institutions can regain or reaffirm their solidarity and agency with surrounding communities. Thus, this research wants to emphasize that the frequent disasters occurring in Nganjuk Regency require a community development activity to reduce the risk of disasters that arise through the Destana program. Many people do not yet understand disaster management activities that adequatelyencourage the Nganjuk BPBD to make community-based risk reduction efforts. In the context of this research, the theoretical study that the researcher explained was made to obtain an explanation of community development through the Destana program in Nganjuk Regency as an effort to reduce risk. That is due to the low level of knowledge of disasterprone people in disaster preparedness.

Destana was intentionally formed in Nganjuk Regency considering the many disasters that occurred in disaster-prone villages such as drought, flood, strong wind/tornado, land and forest fires, and land Avalanche. Nganjuk Regency is one of 20 regencies/cities prone to disasters from 3 provinces, Central Java, East Java, and West Java, which are frequently affected by disasters in Indonesia in 2017 (BNPB, 2018). This regency is also included in 29 regencies/cities in East Java Province, which poses a highrisk class. The geographical location of the Nganjuk Regency is between $111^{\circ} 5^{\prime}$ to $112^{\circ} 13^{\prime}$ East and $7^{\circ} 20^{\prime}$ to $7^{\circ} 59^{\prime}$ South with an area of $122,433 \mathrm{Km}^{2}$ has a topography in the form of lowlands and mountains, which causes disasters often appear in each season.

Preparedness activities to deal with disasters are needed to reduce the impact of a disaster. In this case, the disaster that occurred in Nganjuk Regency due to its geographical location, namely in the southern region, is dominated under the slopes of Mount Wilis with potential landslides, and then there are forest areas which naturally in the dry season can potentially lead to forest fires. While drought disasters often occur in the northern region of this regency. However, when a tornado also hit the rainy season

\section{2| Journal of Local Government Issues (Logos), 4 (1), March 2021, pp 60- 75 ISSN : 2620-8091 print | 2620-3812 online}


in the regency. These disasters will impact the occurrence of casualties, damage, loss, and life disruption. Based on the results of the study of the Disaster Risk Index (DRI) of Indonesia released by BNPB in 2015 to 2018, it states that DRI in Nganjuk Regency is in the medium-high risk class with a score of 152.8, the following researchers present in the table below:

Table 1. Nganjuk Regency Disaster Risk Index in 2015, 2016, 2017, and 2018

\begin{tabular}{|c|c|c|c|c|c|c|}
\hline \multirow{3}{*}{ No } & \multirow{3}{*}{ Type of Disaster } & \multicolumn{4}{|c|}{ Score } & \multirow{3}{*}{$\begin{array}{l}\text { Categ } \\
\text { ory }\end{array}$} \\
\hline & & 20 & 20 & 20 & 20 & \\
\hline & & 15 & 16 & 17 & 18 & \\
\hline & $\begin{array}{l}\text { Multihazard / } \\
\text { Combination } \\
\text { Disaster }\end{array}$ & $2.8^{15}$ & $2.8^{15}$ & $2.8^{15}$ & $2.8^{15}$ & High \\
\hline 101 & Flood & $6^{33 .}$ & 633. & 633. & 633. & High \\
\hline 102 & Landslide & 24 & 24 & 24 & 24 & High \\
\hline 105 & $\begin{array}{l}\text { A whirlwind or } \\
\text { quail }\end{array}$ & $6^{13 .}$ & .6 & 613. & 613. & High \\
\hline 106 & Drought & 24 & 24 & 24 & 24 & High \\
\hline 107 & $\begin{array}{l}\text { Land and forest } \\
\text { fires }\end{array}$ & 36 & 36 & 36 & 36 & High \\
\hline 108 & Earthquake & $6 \quad 21$. & 621. & $6^{21 .}$ & 621. & High \\
\hline
\end{tabular}

Source: (Amri et al., 2016)

According to these data (Table 1), from 2015 to 2018, DRI in Nganjuk Regency gets a high and fixed score of 152.8. The DRI calculation is obtained from calculating the potential for victims and its impact from a disaster. Thus, the calculation is focused on the potential for the possibility and extent of the impact measured or calculated based on each hazard's exposure and a combination of several existing disasters (multihazard). Seeing this problem, the Regional Disaster Management Agency (BPBD) of Nganjuk Regency in 2015 submitted a proposal to obtain support for establishing Destana resources from BNPB, which was later accepted in 2016. As an initial implementation, BNPB formed 2 (two) Destana in disaster-prone villages known to have high disaster threats in the Regency Nganjuk, namely Bareng Village and Kebonagung Village, Sawahan Sub-Regency. The establishment of this facility is a strategy to create resilience in the face of disasters, form public awareness of the importance of knowledge about a disaster, and self-defense training during disasters. Then in 2018, the Nganjuk Regency Government issued a Regent Decree Number: 188/231 / K / 411.012 / 2018 concerning Location Determination of Disaster-Prone Villages in which there were 100 villages out of 284 villages that were recorded as disaster-prone. Of the 100 disaster-prone villages, 64 of them have 2 (two) or more potential threats. Of the 64 disaster-prone villages, 52 Destana were formed, namely 2 (two) Destana in 2016 by BNPB, then by BPBD Nganjuk, 10 Destana were formed in 2018, 10 Destana at the beginning of 2019, and 30 Destana at the end of 2019. 
The Destana program's specialty in the Nganjuk Regency compared to other regions in Indonesia is the ability of Nganjuk BPBD in forming 50 Destana in only two years (2018 and 2019). It is inseparable from the role of the Regional Government that provides the Regional Revenue and Expenditure Budget to be allocated to the implementation of the Destana program and the active involvement of village governments and disaster-prone village communities. So that Destana in Nganjuk Regency also has been able to get an award at the level of East Java Province, namely Kebonagung Village, Sawahan Sub-Regency, by winning the award as the best Destana through the Mid-category Disaster Resilient Village Competition in the Administration and Legislative Level in East Java Province in 2018 and 2019, Nganjuk Regency also received an award again as the best Destana in the middle category, namely Salamrejo Village, Berbek Sub-Regency (Amri et al., 2016).

In this case, the Destana was deliberately formed in Nganjuk Regency by considering the many disasters in disaster-prone villages such as drought, flood, strong winds/tornadoes, land and forest, fires, and landslides. To reduce the risk of disasters in these disaster-prone areas, Destana was formed hoping that disaster management in these villages will be able to sprint accurately, and involve the community as a whole and sustainably. Besides, bearing in mind that the community is the first party to face a disaster as well as being the victim or the most disadvantaged party when a disaster occurs in a disaster-prone area, it is necessary to make several efforts and increase the capacity of the disaster-prone community in anticipating the possibility of a disaster occurring. Where it can reduce, prevent or eliminate the risk of disasters that will be obtained from the occurrence of disasters, thus the purpose of this research is the formation of a resilient and independent community in dealing with disasters so that the risk of disasters that arise can be reduced in Nganjuk Regency.

Several previous studies have placed the village as one of the centers for disaster management. In the findings (Oktaviani, Putri, \& Hartanto, 2020) and (Pratiwi, 2019) in Pilangsari Village, Bojonegoro Regency, (Ginting \& Dewi, 2020) in Kutai Kartanegara Regency and (Mahdi \& Mulyani, 2016) in Dua Gempong Pesisir Village, Aceh Besar Regency Destana at least succeeded in increasing awareness and active participation of the community to be involved in disaster management. From the implementation aspect of the findings (Aini, Ulfah, \& Afala, 2018; Hendriyanto \& Permata, 2017) in Sirnoboyo Village, Pacitan Regency, Pasawahan Village, Garut Regency (Buchari, Santoso, \& Marlina, 2017) and Kutai Kartanegara Regency (Ginting \& Wijayanti, 2019), it appears that organizational characteristics (village bureaucratic readiness) are one of the obstacles to the effectiveness of the Destana program. The conclusion (Hijri \& Achmad, 2019) in Malang Regency that village capacity is crucial the Destana program's success. This article fills in the previous study's gaps with the fundamental explanation that Nganjuk Regency, which has a high status of disaster risk for victims and impacts as a research locus, has never been described before.

\section{METHOD}

Qualitative research is a research method used to examine objects naturally with researchers as crucial instruments, and the results of qualitative research are to understand the meaning, uniqueness, and construction of phenomena (Sugiyono,

\section{4| Journal of Local Government Issues (Logos), 4 (1), March 2021, pp 60- 75 ISSN : 2620-8091 print | 2620-3812 online}


2008a). The descriptive approach is carried out to produce data in the form of words and intends to describe efforts to reduce community-based disaster risk with community development through the Destana program in Nganjuk Regency (Sugiyono, $2008 b)$. In this case, researchers used a qualitative method with a descriptive approach because it allows researchers to understand and find the data or information needed when researchers are in the field. In this case, researchers in the field as a direct observer of various activities to be studied determine the research results, then employing field observations, researchers can find, analyze, and collect data directly.

The data used in this study came from two types of sources, primary data sources, and secondary data sources. Primary data sources are data sources that researchers get directly from the Nganjuk BPBD, Destana volunteers, and the relevant Village Government. Secondary sources are not directly obtained from informants but through documents, scientific journals, scientific magazines, or books or what is commonly referred to as library studies related to community-based risk reduction through the Destana program in Nganjuk Regency (Sugiyono, 2008b). Data collection techniques in this study used observation, interviews with fiveinformants (Aripin, S.Kom as Head of Government Division in Gampeng Village, Drs. Nugroho as Head of Prevention / Mitigation and Preparedness of BPBD Nganjuk, Ektavianto AN, S. Pd as Facilitator and Pusdalops BPBD Nganjuk, Nurhuda as Volunteer Destana Sawahan, and Prayoga, S. Pd as the Village Staff of Kebonagung), and documentation. The data analysis techniques that researchers use in this study include interview transcripts, data reduction, and then analysis. Researchers enter data obtained in the field through interviews using interview guidelines and then reduced by sorting out what can be used and not in this study - then analyzed and incorporated into the discussion results.

\section{RESULTS AND DISCUSSION}

Destana Development is one of the efforts to reduce community-based disaster risk, which is done by increasing the community's preparedness capacity as the main actor. Communities in Destana are actively involved in analyzing, studying, monitoring, handling, evaluating, and reducing disaster risks in their area by utilizing local resources. This is supported by the existence of Law No. 6 of 2014 concerning Villages article 1 paragraph 12 , which states that village community empowerment is an effort to develop community welfare and independence by increasing knowledge, skills, attitudes and behavior, awareness, and utilization of resources through programs or policies with assistance to village communities. Then based on the findings of researchers in the field and literature studies that are associated with the theory of community development from (Bhattacharyya, 2004) regarding community development as an effort to reduce disaster risk through the Destana program in Nganjuk Regency, data and information are obtained through interviews with informants who found in the field and study documentation that:

\section{Increase Solidarity and Institutionalization in Self-Help}

The principle of self-reliance is to value and prioritize the community's ability compared to the help of others (Iryana, 2018). Self-help is the opposite of dependency, meaning self-reliant power or power, which is to build and utilize institutions by mobilizing cultural and material assets of the community to increase solidarity to

\section{5| Journal of Local Government Issues (Logos), 4 (1), March 2021, pp 60- 75 ISSN : 2620-8091 print | 2620-3812 online}


reduce the risk of disasters in disaster-prone areas in Nganjuk Regency, for example: on the technical knowledge of disaster management from pre, during, until post-disaster, the use of first aid tools or disaster preparedness practice tools, and the deployment of a workforce consisting of disaster-prone communities and Destana volunteers.

Community development is characterized by solidarity and mutually beneficial agencies in community development through training and outreach (Bhattacharyya, 1995). The principle rests on the human concept that when they are healthy, they are willing and able to look after themselves, reciprocate, be productive, are more likely to give rather than receive, be active than passive, and be creative rather than consume. Furthermore, the initial concept of community-based is the principle of salvation that starts from the community itself. So, when the community has been able to save themselves, they have also been able to save others. The community obtained this rescue knowledge from the implementation of the establishment of Destana in related disaster-prone villages (Amri et al., 2016). Therefore, integrating a community-based disaster risk reduction program as a development program in the village becomes ideal for disaster-prone communities. Where to realize the first level Destana program towards the main level, the central and regional governments must carry out a continuous mentoring process to the community.

While this practice has the most important goal of avoiding dependency between disaster-prone communities and institutions, namely the Regional Disaster Management Agency (BPBD) of Nganjuk Regency, which houses disaster, so between communities have a sense of unity and interest in being resilient in the face of disasters, they can solve existing problems independently. This capability is inseparable from the role of the Nganjuk Regional Disaster Management Agency (BPBD) as the party that formed Destana by carrying out several activities in the formation of Destana, such as disaster risk assessment, disaster management planning in the village. The formation of Disaster Risk Reduction Forum (FPRB) to increase citizens and village officials' capacity in disaster management through disaster training activities, guiding disaster management in village development plans and Legalizing Destana. The Destana Program is community development from community-based disaster management activities that have existed before through hereditary teaching from ancestors and selftaught people when facing disasters.Before the Destana program, in related disasterprone villages (Amri et al., 2016), local knowledge about a disaster in rural communities is spoken for generations from one generation to the next. So when the Nganjuk BPBD formed Destana in disaster-prone villages in Nganjuk Regency, the community was ready and exchanged knowledge.

With the presence of Destana in disaster-prone villages, it has been able to increase solidarity among disaster-prone communities in dealing with disasters that will, when, or have occurred in their villages in a resilient and independent mannerimpact or risk of disasters that can be reduced. In this case, one example of preparedness activities from the people of the northern region of Nganjuk Regency explains that the village government of Gampeng Village, Ngluyu Sub-Regency is communicating and cooperating with FPRB or the forum for disaster risk reduction, Community Protection (Linmas) and other non-governmental organizations to implement several activities. Preparedness such as "getok tular" which is an appeal

66| Journal of Local Government Issues (Logos), 4 (1), March 2021, pp 60 - 75 ISSN : 2620-8091 print | 2620-3812 online 
when there is a sign of disaster for example, when heavy rains have urged the people not to sleep and if solid winds accompany it then do not be in the house but go out and head to the evacuation site under the path created by the community when forming Destana. That is because disaster-prone areas such as Gampeng Ngluyu Sub-Regency's village have the potential for different natural disasters in each hamlet (see Figure 1). So the community must understand the conditions in their area based on the disasterprone maps made at the time of the formation of Destana. Activity "getok tular" is a form of local wisdom from knowledge about disaster warnings for everyone when a disaster occurs (Indrayani, 2016).

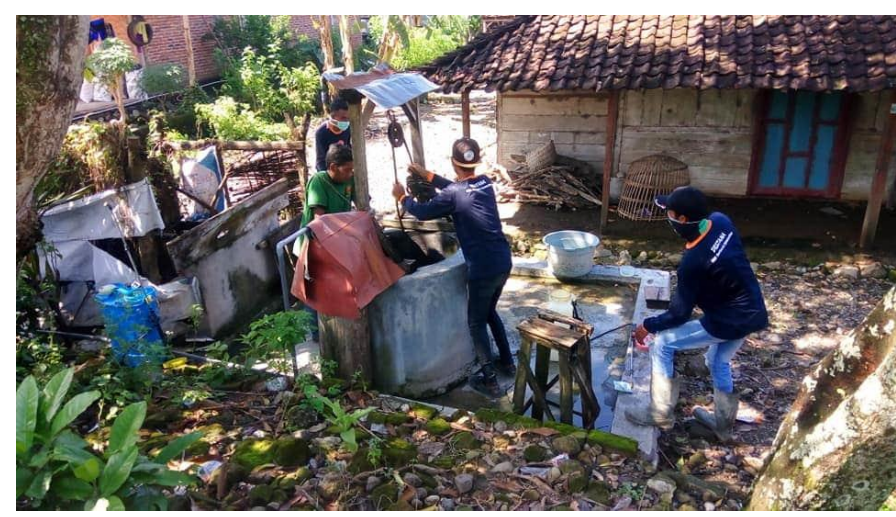

Figure 1. Community Service Activities in Gampeng Village

Source: Gampeng Village Government Archive Ngluyu Sub-Regency, 2020

In addition to the "getok tular" activities, pre-disaster activities are also carried out by anticipating the emergence of disasters in their villages, such as community service activities for spraying disinfectants in the Gampeng Village environment for coronavirus anticipation. Knowledge related to disaster management is limited to knowledge of local wisdom and was obtained from the Nganjuk BPBD when Destana was formed and used in practice. The process of preparedness, evacuation, and rehabilitation that refers to the knowledge and practice obtained from establishing Destana is carried out jointly and cooperatively by the community Where solidarity is created independently in the disaster-prone community can reduce losses due to disasters so that the community can carry out disaster management activities at the village level. Itis the result of public awareness of the importance of reducing the risk of large disasters from the prevention stage to the stage when disasters emerge in their areas under the supervision of the Nganjuk BPBD. Therefore, the Destana program in Nganjuk Regency has been able to form a disaster-resilient and independent community in overcoming existing disasters.

The village's condition that is safe from disasters will undoubtedly have a good impact on the community by following the calls and orders from the Nganjuk BPBD and the Village Government. Communicating and coordinating through groups on WhatsApp, utilises handy talk (HT), and practical help tools are given. It continues to independently carry out disaster management programs because the purpose of this program is to make an independent village in facing disasters from the preparedness stage, disaster response to the rehabilitation phase. People who initially lacked

67| Journal of Local Government Issues (Logos), 4 (1), March 2021, pp 60- 75 ISSN : 2620-8091 print | 2620-3812 online 
understanding of disaster management activities at the village level in solidarity became aware of and were able to save themselves and others based on the knowledge they got from the Nganjuk BPBD during the formation of Destana. This solidarity attitude can make the community no longer dependent on the Nganjuk Regency BPBD in tackling disasters in the disaster-prone villages. When the disaster arrives, the Nganjuk BPBD is no longer worried when the community faces a disaster because the distance of the Nganjuk BPBD office location to the disaster-prone areas is far enough that it takes time to arrive at the disaster scene. Instead, the community will independently carry out disaster management actions in cooperation based on the knowledge of natural descent and obtained from BPBD Nganjuk while waiting for representative staff from BPBD Nganjuk to come to the location of the disaster. Such as a forest fire disaster on the slopes of Mount Wilis, which occurred on 22- July 23, 2020, to be precise in Sawahan Sub-Regency, Nganjuk Regency and a tornado in Gampeng Village, Ngluyu Sub-Regency on November 25, 2019.

\section{Needs felt together}

Development activities must respond to community needs on request where the intended purpose is the existence of a community-based program that can reduce the risk of disasters in disaster-prone areas. At the same time, the intended request is the community's ability to cope with sudden disasters. In this case, the perceived need confirms human variation in feeling a demand. This request results from a coordinating network between the community, village government, and the Nganjuk Regency BPBD, which is then given a foundation of mutual trust and mutual benefit that allows people to take collective steps to overcome the disasters arise together (see Figure 2). Before the community-based program implemented by the Nganjuk BPBD in disaster-prone villages, the community in general already had a disaster knowledge base that needed to be developed. In practice, with the Destana program's existence, the community is felt to be able to cope with disasters that arise. After the existence of Destana, the disaster-prone village community has been able to be tough, independent, and alert in handling disasters from the moment until after they appear in their village while being monitored and accompanied by the Nganjuk BPBD.

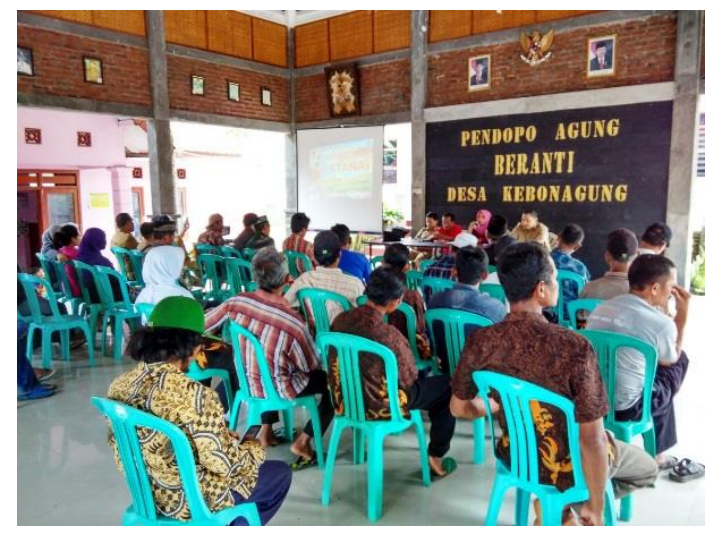

Figure 2. Activities of Forming a Disaster Resilient Village in Kebonagung Village in 2016 Source: Kebonagung Village Government Archives, 2016

68| Journal of Local Government Issues (Logos), 4 (1), March 2021, pp 60 - 75 ISSN : 2620-8091 print | 2620-3812 online 
The establishment of Destana in disaster-prone areas is done by exploring the community's knowledge, and experience of threats/ disasters carried out at the beginning of the activity, as an effort to build understanding/ common perception and thinking of the community (Oktari, 2019). The establishment of Destana in Nganjuk Regency has the objectives of implementing community-based disaster reduction and encouraging community resilience and independence in facing disasters at the village level. Gathering public knowledge on their area to carry out preparedness activities such as in the southern region of Nganjuk Regency, namely Kebonagung Village and Ngliman Village, Sawahan Sub-Regency, where every disaster-prone village established by Destana will be made an evacuation route by the Nganjuk BPBD. So if there are events such as strong winds, landslides, floods, or land and forest fires, the community can evacuate themselves and others to places that have been considered safe and used as temporary shelter posts. Evacuation route signs are installed at the crossroads/roadside directions to the evacuation posts that have been determined in the disaster-prone map in every Destana that is formed (see Figure 3). So that if there are signs of a disaster appearing, the community will be encouraged to go directly to the evacuation post's location by following the evacuation route signs determined.

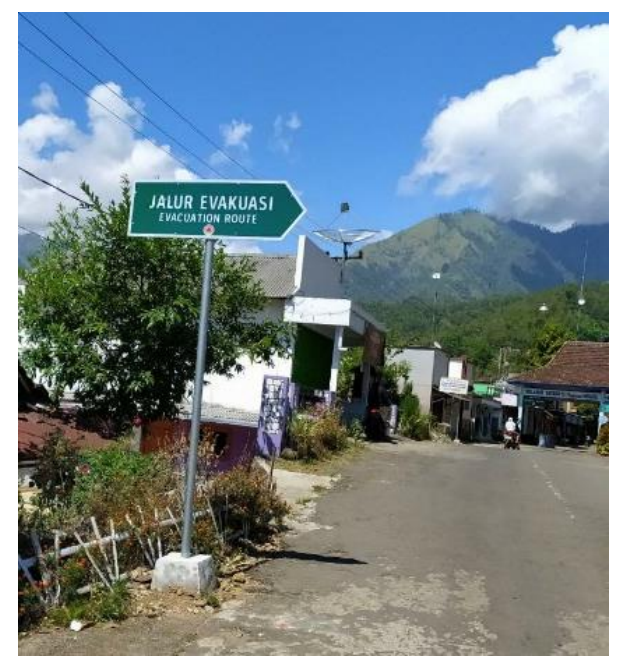

Figure 3. Directions for Evacuation Paths in Ngliman Village, Sawahan Sub-Regency

Source: Author's Documentation, 2020

Installing the evacuation route signs is part of the Destana program's implementation, which is expected to help the community when a disaster strikes. Evacuation signs installation at a certain point following the disaster-prone map was created at the time of the formation of Destana. As a map of disaster-prone areas in Kebonagung Village, Sawahan Sub-Regency, contains disaster-prone locations and potential disasters in Kebonagung Village (see Figure 4). This disaster-prone map is a shared need that includes the results of the formation of Destana in the form of disaster documents and is made by the community with guidance from the Nganjuk BPBD. The community is expected to analyze and understand the potential and ways of dealing with disasters that come in their area. 


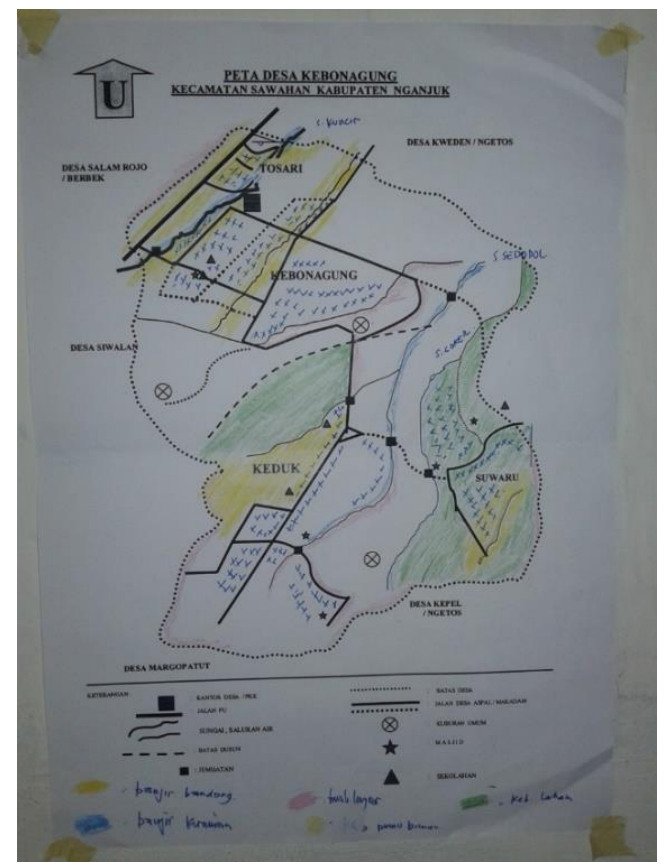

Figure 4. Disaster-prone Map in Kebonagung Village

Source: Kebonagung Village Government Archives, 2016

In addition to the evacuation route signs and disaster-prone maps, disaster documents in disaster-prone villages also contain legislation made by the relevant Village Government to appeal to the Nganjuk BPBD. One of the villages that have legislation is Kebonagung Village, Sawahan Sub-Regency, where the village has received the best Destana award in Administration and Legislation in East Java. Kebonagung Village Government ratifies Village Head Decree Number: 188/26 / K / 411.507.09 / 2020 concerning Disaster Risk Assessment which is the basis for disaster management activities in Kebonagung Village and contains disaster documents from pre-postdisaster activities and FPRB arrangement. Based on the Village Head's decision, it makes the community prone to disasters, especially Kebonagung Village, capable and willing to participate in disaster management activities to reduce the risk of existing disasters. However, although legislation has not yet been formed for other regions, the community is willing to be involved because of the role of the FPRB, the Village Government, and the Nganjuk BPBD in raising public awareness of the importance of disaster risk reduction.

\section{Society participation}

According to (Bhattacharyya, 2004) community participation is to take part in problem-solving activities by creating/adding value to meet collective needs. In this case, the existence of Destana in disaster-prone villages in Nganjuk Regency has been able to reduce the risk of disasters arising from community participation in creating cooperation by coordinating horizontally well and vertically that is good and integrated. Community participation in the implementation of the Destana program in Nganjuk Regency, one of which is in Kebonagung Village, shows that community participation in the Destana program's implementation has actively involved the community. The 
Nganjuk BPBD government representative invites the public by talking together privately, such as when guarding a mobile security post or outreach activities at a village hall related to disaster management activities. However, this socializationis considered to be ineffective because many people do not understand it with certainty, so that the Kebonagung Village Government more to private socialization to emphasize the participation of the community in activities to reduce the risk of disasters.

Coordination concerns the communication problem of some information/forming a suitable administrative structure (see Figure 5). However, it also involves more fundamental issues, namely the practice of exercising power to unite some competing skills and concerns (skills and interests) and lead them towards a common goal. A meeting needs to be held to discuss disaster risk reduction activities to unite some of these skills and concerns.

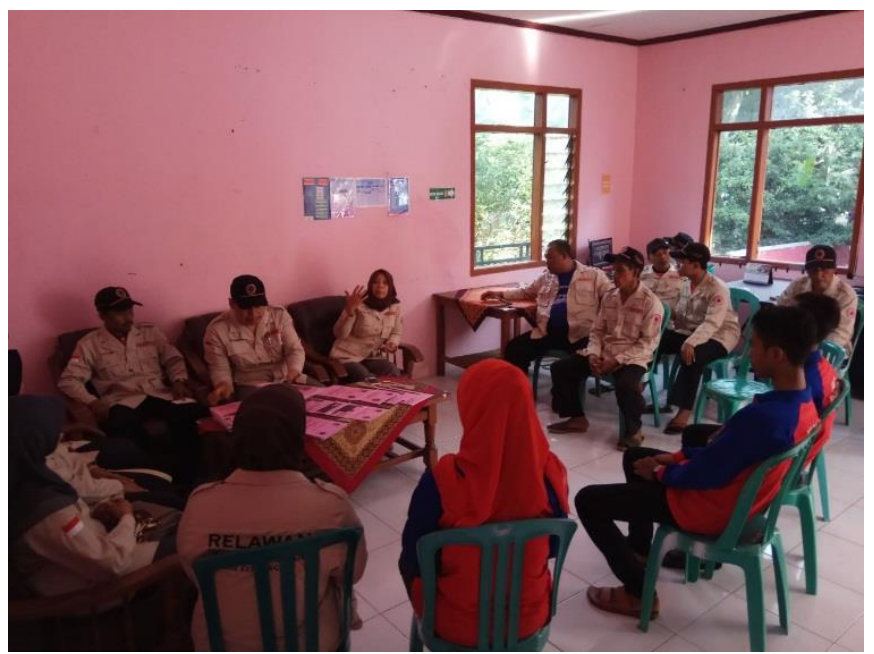

Figure 5. Cross-Generational and Institutional Coordination Meeting in Kebonagung Village

Source: Government of Kebonagung Village, Sawahan Sub-Regency, 2016

The cross-generation and institutional coordination meeting activities are prevention planning activities represented by people of different ages, government, and private sectors. The role of the three pillars (government and regional government, community, and business entities) as stipulated in Law number 24 of 2007 about Concerning Disaster Management, disaster cannot be separated in the development process. The government alone cannot do the work because the government's responsibility is to unite the three pillars so that they can work in synergy (Hasanah, 2019).

Community participation that is inseparable from the coordination of the threepillars was also conveyed by (Nurasa, 2016) in his research on the analysis of rural community institutional capacity building programs in which the role of the community in rural development was designed to be optimally utilized, and this differs when compared with the previous program that the main program actors were the apparatus. In the National Program for Empowerment of Independent Community in Rural Areas, there is a synergy of roles among development stakeholders in rural areas (government, community, and business world) as program actors. Destana program's implementation

71| Journal of Local Government Issues (Logos), 4 (1), March 2021, pp 60- 75 ISSN : 2620-8091 print | 2620-3812 online 
was also conveyed by (Riyadhi, 2018) Where community participation has been carried out well by the people of Sungenlegowo Village, this can be seen from the commitment of the Sungenlegowo Village community in the implementation of the Destana program.Then the citizens' enthusiasm in participating in education is provided by the Regional Disaster Management Agency (BPBD). Gresik is a simulation of disaster management and cooperation, which is done when there is a village or region or the area around which is affected by a disaster, the people of Sungonlegowo Village quickly help.

The threepillars of collaboration can be seen in handling intensewind disasters in the Gampeng Village, Ngluyu Sub-Regency, when a community is affected by a strong wind or tornado disaster, the community, non-government parties and the government collaborate to help the affected parties by cleaning up the disaster building debris or other resource provision (see Figure 6).

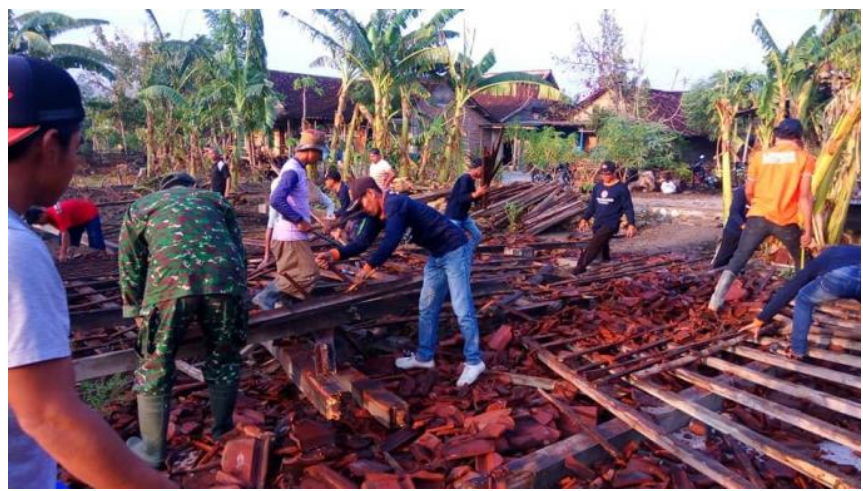

Figure 6. Cooperation to clean up the remaining material from the strong wind disaster in the Village of Gampeng

Source: Gampeng Village Government Archive, 2019

The community did participate in the local environment, while outside the area, the people who are appointed to become Destana volunteers are selected to become Destana Facilitators after participating in the Destana Training of Facilitators (see Figure 7) in related years to become Destana's companion who will be formed later in Nganjuk Regency and other Regencies.

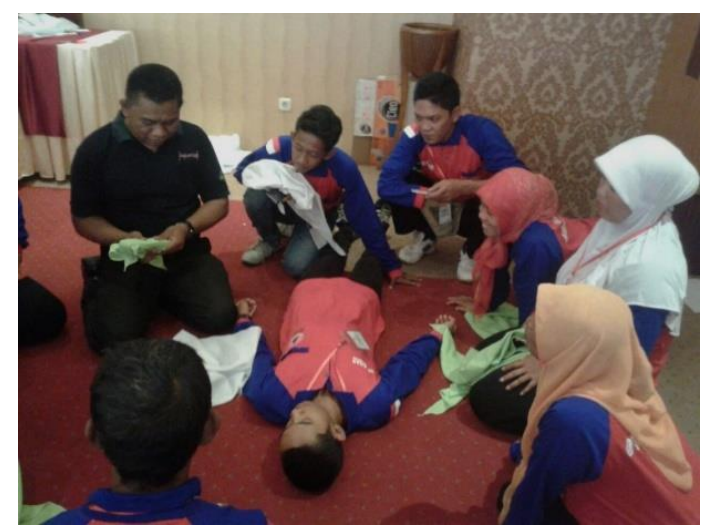

Figure 7. Strengthening the Capacity of Disaster Management Communities Source: Kebonagung Village Government Archive, 2018 
Destana volunteer improvement activities are part of efforts to reduce disaster risk by forming Destana volunteers who are more reliable and able to be a companion for disaster-prone communities that will be formed next. Community participation in the implementation of the Destana program, both in the form of statements and in the form of activities by providing input of thought, energy, time, expertise, capital, materials, as well as taking advantage of and enjoying the results of the existence of Destana in related disaster-prone villages is inseparable from trust the community themselves to be involved in disaster risk reduction activities. In this case, community solidarity and social integrity when a disaster occurs results in social responsibility and community commitment to participate in disaster management activities from pre, during, and after the disaster. The willingness and ability of the community to change or improve the situation before and after a disaster occur through deliberation to reach consensuses such as in making decisions in the preparation of related village FPRB, resulting in community sensitivity and responsiveness to disasters and the need for disaster risk reduction that can be implemented. In this case, the Nganjuk Regency BPBD and the related Village Government, together with disaster-prone communities, coordinate with each other to get involved in the Destana program's implementation to reduce the risk of disasters that arise.So that disaster-prone communities in Nganjuk Regency can now be resilient and independent in overcoming existing disasters.

\section{CONCLUSION}

The disasters that often occur in Nganjuk Regency make the government that oversees the disaster, namely BNPB and BPBD from Destana. The Disaster Resilient Village program aims to increase solidarity and institutionalization in a self-supporting manner in disaster-prone communities in Nganjuk Regency, which is considered adequate. The Destana program, cooperation, social sense, awareness among residents around disaster-prone areas, and knowledge about countermeasures for disaster risk reduction efforts also increase. The disaster-prone community has been able to be independent and resilient in dealing with disasters that occur from the guidance of the Destana Facilitator from the Nganjuk BPBD so that the risk of disasters caused is reduced compared to before the Destana program. The need shared by disaster-prone communities in Nganjuk Regency is the existence of community-based disaster management programs to reduce the risk of disasters caused.

The Regional Disaster Management Agency (BPBD) Nganjuk Regency has provided these needs by forming Destana in disaster-prone villages in Nganjuk Regency. The Destana program's implementation is a community development activity in dealing with disasters that have occurred. The benefits of disaster-prone communities have been felt so that researchers and informants consider the Destana Program running effectively and successfully reducing the risk of disasters caused by disasters that occur. Appeared in disaster-prone areas in Nganjuk Regency based on the data the researchers got and monitoring informants in the field so far. This program will not run effectively if community participation in disaster risk reduction activities through the Destana program is not supportive. Therefore, BPBD Nganjuk and the village government are expected to continue to carry out socialization and preparedness activities to the community. However, the community's role is also crucial in the smooth running of this program and disaster management activities in Nganjuk Regency so that the community

73| Journal of Local Government Issues (Logos), 4 (1), March 2021, pp 60 - 75 ISSN : 2620-8091 print | 2620-3812 online 
will continue to carry out disaster activities voluntarily together, which proves that the Destana program has formed a disaster-prone community that is resilient and independent in the face of disasters.

\section{REFERENCES}

Aini, N., Ulfah, I. F., \& Afala, L. M. (2018). Efektivitas Program Desa Tangguh Bencana Di Desa Sirnoboyo Kecamatan Pacitan Kabupaten Pacitan Tahun 2017. Journal of Governance and Policy, 4(2), 50-61.

Amri, M. R., Yulianti, G., Yunus, R., Wiguna, S., Adi, A., Ichwana, A., . . Septian, R. (2016). Risiko bencana indonesia. Badan Nasional Penanggulangan Bencana. Jakarta.

Bhattacharyya, J. (1995). Solidarity and agency: Rethinking community development. Human organization, 54 60-69. https://doi.org/10.17730/humo.54.1.m459ln688536005w

Bhattacharyya, J. (2004). Theorizing Community Development. Journal of Community Development Society, 34(2), 5-34. https://doi.org/10.1080/15575330409490110

BNPB. (2018). Disasters in Indonesia in 2017

Buchari, A., Santoso, M. B., \& Marlina, N. (2017). Pengembangan Kapasitas Kelembagaan Desa Tangguh Bencana di Kabupaten Garut (Studi Kasus di Desa Pasawahan Kecamatan Tarogong Kaler). JAKPP (Jurnal Analisis Kebijakan \& Pelayanan Publik), 3(1), 49-62. https://doi.org/10.31947/jakpp.v3i1.4729

Ginting, A. H., \& Dewi, T. (2020). Strategi Pemberdayaan Masyarakat Oleh Badan Penanggulangan Bencana Daerah Kabupaten Kutai Kertanegara Dalam Mewujudkan Desa Tangguh Bencana (Studi Pada Desa Loa Ipuh dan Desa Purwajawa Kabupaten Kutai Kertanegara). Jurnal Tatapamong, 17-34. https://doi.org/10.33701/jurnaltatapamong.v2i1.1233

Ginting, A. H., \& Wijayanti, T. D. (2019). Pemberdayaan Masyarakat Melalui Program Desa Tangguh Bencana di Kabupaten Kutai Kartanegara. TRANSFORMASI: Jurnal Manajemen Pemerintahan, 42-57. https://doi.org/10.33701/jtp.v11i2.695

Hasanah, B. (2019). Akuntabilitas Public Dalam Manajemen Bencana Tsunami Selat Sunda. CosmoGov: Jurnal Ilmu Pemerintahan, 5(2), 174-188. https://doi.org/10.24198/cosmogov.v5i2.22563

Hendriyanto, A., \& Permata, N. (2017). Menuju Desa Tangguh Bencana di Desa Sirnoboyo. Transformasi: Jurnal Pengabdian Masyarakat, 13(1), 1-13. https://doi.org/10.20414/transformasi.v13i1.1976

Hijri, Y. S., \& Achmad, Z. (2019). Penguatan Kapasitas Desa Tangguh Bencana di Kabupaten Malang. Khadimul Ummah, 3(1), 8-18. http://dx.doi.org/10.21111/ku.v3i1.3605

Indrayani, D. (2016). Pengantar Sosiologi Pedesaan. Jakarta: Kencana.

Iryana, A. B. (2018). Pemberdayaan Masyarakat Petani Dalam Meningkatkan Kesejahteraan Hidup di Kecamatan Compreng Kabupaten Subang. Jurnal Academia Praja, 1(02), 125-140. https://doi.org/10.36859/jap.v1i02.69

Kodoatie, R. J. (2006). Pengelolaan Bencana Terpadu. Jakarta: Yayasan Watampone.

Kushandajani, K. (2017). Implikasi UU No. 6 Tahun 2014 tentang Desa terhadap Penyelenggaraan Pemerintahan Desa. JIIP: Jurnal Ilmiah Ilmu Pemerintahan, 2(1), 53-64. https://doi.org/10.14710/jiip.v2i1.1635

74| Journal of Local Government Issues (Logos), 4 (1), March 2021, pp 60- 75 ISSN : 2620-8091 print | 2620-3812 online 
Mahdi, S., \& Mulyani, E. S. (2016). Kajian Empiris Program Desa Tangguh Bencana (Destana) Terhadap Ketangguhan Masyarakat Pesisir Dalam Menghadapi Bencana Tsunami: Studi Kasus di Dua Gampong Pesisir Kabupaten Aceh Besar. Jurnal Ilmu Kebencanaan: Program Pascasarjana Unsyiah, 3(4), 142-148.

Nasdian, F. T. (2015). Sosiologi umum. Jakarta: Yayasan Pustaka Obor Indonesia.

Nurasa, H. (2016). Analisis Program Pengembangan Kapasitas Kelembagaan Masyarakat Desa: Suatu Studi Pada Program Pengembangan Masyarakat Miskin di Perdesaan. CosmoGov: Jurnal Ilmu Pemerintahan, 2(1), 23-38. https://doi.org/10.24198/cosmogov.v2i1.11849

Oktari, R. S. (2019). Peningkatan Kapasitas Desa Tangguh Bencana. Jurnal Pengabdian kepada Masyarakat (Indonesian Journal of Community Engagement), 4(2), 189197. https://doi.org/10.22146/jpkm.29960

Oktaviani, A. D., Putri, F. A., \& Hartanto, M. T. (2020). Pemberdayaan Masyarakat melalui Program Desa Tangguh Bencana (DESTANA) Sebagai Upaya Mitigasi Banjir Rob di Kabupaten Cirebon. Jurnal Pusat Inovasi Masyarakat (PIM), 2(3), 357-362.

Pratiwi, D. I. (2019). Partisipasi Masyarakat Dalam Program Desa Tangguh Bencana (Destana) di Desa Pilangsari Kabupaten Bojonegoro. Publika, 7(7).

Riyadhi, S. (2018). Partisipasi Masyarakat Dalam Program Desa Atau Kelurahan Tangguh Bencana (Destana) di Desa Sungonlegowo Kecamatan Bungah Kabupaten Gresik. Publika, 6(3).

Sugiyono. (2008a). Metode Penelitian Kuantitatif Kualitatif dan R\&D. Bandung: CV. Alfabeta

Sugiyono. (2008b). Metode Penelitian Kuantitatif Kualitatif dan R\&D. Bandung: CV. Alfabeta.

Yustika, A. E. (2015). Pengembangan Desa. Jakarta: Kementerian Desa, Pembangunan Daerah Tertinggal, Dan Transmigrasi. 